\title{
KOMBINASI METODE METODE FINITE STATE MACHINE DAN GAME-BASED LEARNING PADA GAME "ESCAPE FROM COV-MADNESS"
}

\author{
Daniel Eka Wijaya, Karina Auliasari, Hani Zulfia Zahro' \\ Program Studi Teknik Informatika S1, Fakultas Teknologi Industri \\ Institut Teknologi Nasional Malang, Jalan Raya Karanglo km 2 Malang, Indonesia \\ Daniel.ekawijaya@gmail.com
}

\begin{abstract}
ABSTRAK
Permasalahan mengenai banyaknya angka kasus positif COVID-19 yang bermula pada awal tahun 2020 membuat semua orang cemas akan keselamatan dirinya bahkan keluarga mereka sendiri. Kurangnya kepatuhan akan protocol kesehatan merupakan salah satu penyebab meningkatnya angka positif COVID-19. Untuk itu, diperlukan pengembangan game sosialisasi tentang bagaimana cara menerapkan protocol kesehatan. Sosialisasi dengan menggunakan media game merupakan salah langkah yang efisien untuk membuat masyarakat lebih patuh dan taat akan protocol kesehatan. Dengan adanya game dapat membuat pemainnya merasakan rasa senang ketika bermain, selain itu juga dapat menanamkan pesan tersirat ke dalam game tersebut.

Pada penelitian ini peneliti menggunakan kombinasi metode Finite State Machine (FSM) dan metode Game Based Learning pada game. Metode FSM ini diterapkan pada 3 level dengan bentuk yang berbeda-beda untuk tiap levelnya. Sedangkan metode Game Based Learning diterapkan pada mini-games diantara salah satu level yang ada dalam game. Game ini dibuat dengan menggunakan tools Unity3D sebagai game engine dan Adobe Illustrator sebagai software untuk membuat desain karakter dan aset-aset yang dibutuhkan.

Berdasarkan hasil pengujian yang telah dilakukan, peneliti menggunakan 12 data responden dengan rentang usia yang berbeda-beda pada tiap responden guna mendapatkan hasil pengujian yang baik. Hasil pengujian tersebut yaitu sebesar $100 \%$ responden menyukai game ini, 100\% responden menyatakan bahwa game ini memberikan nilai moral dalam kehidupan sehari-hari, dan sebanyak $91,7 \%$ responden menyatakan bahwa control pada game ini berjalan dengan baik.
\end{abstract}

Kata Kunci : COVID-19, Finite State Machine, Game Based Learning, Game Edukasi, Desktop

1. PENDAHULUAN

1.1 Latar Belakang

COVID-19 merupakan virus yang dapat menyerang siapa saja mulai dari rentang usia bayi hingga lansia. Virus ini menginfeksi tubuh pada bagian saluran pernafasan. Virus ini menular melalui percikan dahak dari saluran pernafasan. Selain pada bidang kesehatan, dampak dari virus ini juga berdampak pada bidang perdagangan, pariwisata, energi, serta ekonomi [1].

Kurangnya tingkat kesadaran masyarakat akan pentingnya protocol kesehatan membuat angka positif kasus COVID-19 ini melonjak tajam. Banyak masyarakat yang belum, bahkan tidak mematuhi protocol kesehatan yang sudah di sosialisasikan oleh pemerintah.

Oleh karena itu, penulis mengembangkan game yang berhubungan dengan permasalahan tentang COVID-19 yang menyebar secara massif ini. Game yang dibuat bertujuan untuk membuat pemain menikmati permainan dengan perasaan yang senang, menghilangkan perasaan stress melalui sebuah game, serta memberi pesan tersirat kepada para pemainnya ketika bermain sebuah game. Penulis mengembangkan sebuah game yang berjudul "Escape from Cov-Madness" yang dapat dijalankan pada desktop. Game ini bercerita tentang perjalanan seorang anak menuju rumahnya dengan aman di tengah-tengah pandemic COVID-19 yang menyebar secara luas dan massif. Metode Finite State Machine dalam game ini digunakan untuk menentukan reaksi yang diberikan oleh musuh ketika berhadapan dengan karakter utama dalam game. Aksi yang diberikan berupa mengejar dan menyerang pemain ketika berada pada jarak tertentu. Sedangkan metode GameBased Learning digunakan untuk mengedukasi pemain dalam game ini melalui sebuah teka-teki yang berisi tentang edukasi mengenai virus COVID-19. Dengan adanya game ini sebagai sarana untuk sosialisasi terkait protocol kesehatan diharapkan makin banyak masyarakat yang sadar akan rasa patuh terhadap protocol kesehatan yang telah ada.

\subsection{Rumusan Masalah}

Mengacu pada permasalahan diatas, peneliti membuat rumusan masalah yaitu bagaimana menggabungkan metode Finite State Machine sebagai metode untuk menentukan reaksi yang dberikan oleh NPC(Non Player Character) dengan metode Game-Based Learning dalam game Escape from Cov-Madness.

\subsection{Batasan Masalah}

Batasan masalah dalam membuat game Escape from Cov-Madness menggunakan metode Finite State Machine antara lain adalah:

1. Karakter pada game ini dibuat dengan model dua dimensi (2D). 
2. Game ini merupakan game desktop yang dapat dimainkan pada laptop/ PC.

3. Perancangan dan pembuatan komponen pada game ini meliputi karakter, background dan rintangan dikembangkan menggunakan software Unity3D dan bahasa pemrograman C\#.

4. Cerita dan alur cerita yang dirancang pada game ini merupakan cerita fiksi (karangan peneliti).

5. Game ini ditujukan untuk rentang usia 13-22 tahun.

6. Level pada game ini ada 3 level, dimana yang membedakan pada setiap level yaitu komponen musuh, rintangan tiap level, tingkat kesulitan pada tiap level.

7. Tujuan dalam menyelesaikan game ini adalah untuk menghindari ancaman yang dapat menyebabkan karakter utama terserang virus COVID-19 dan menyelesaikan tiap level dengan kondisi masih sehat/ tidak terjangkit virus COVID-19.

8. Pemain tidak diwajibkan untuk menyelesaikan game dengan mengumpulkan semua objektif dalam game, namun objektif itu sendiri memiliki tujuan utama untuk menambah darah pemain.

9. Skor dalam game bertujuan untuk membuat pemain merasa tertantang untuk mengumpulkan objektif sebanyak mungkin.

10. Terdapat mini-games yang berisikan teka teki mengenai virus COVID-19.

11. Perancangan game ini salah satu tujuannya adalah untuk menampilkan beberapa informasi tentang sosialisasi virus COVID-19, namun tidak secara rinci mengenai informasi virus COVID-19 karena itu nama dari game yang dikembangkan adalah Escape from CovMadness.

12. Metode yang diterapkan dalam penerapan reaksi NPC adalah metode Finite State Machine.

13. Metode yang diterapkan dalam mini-games adalah metode Game-Based Learning.

\subsection{Tujuan}

Adapun tujuan dari pembuatan game ini yaitu:

1. Membuat game Escape from Cov-Madness dengan Unity $3 D$ menggunakan metode Finite State Machine dan metode Game-Based Learning.

2. Mengimplementasikan metode Finite State Machine dan metode Game-Based Learning untuk menghasilkan suatu kecerdasan buatan dalam game Escape from Cov-Madness.

\subsection{Manfaat}

1. Memberikan edukasi mengenai virus COVID-19 dalam bentuk game yang menghibur dan menarik.

2. Mengasah otak dalam bermain untuk memenangkan permainan.

3. Membangun kesadaran akan bahaya virus COVID-19 dan menerapkan pola hidup sehat.

\section{TINJAUAN PUSTAKA}

\subsection{Penelitian Terdahulu}

Alqorni di tahun 2017 pada penelitiannya yang berjudul "Penerapan Metode Finite State Machine Untuk Non Player Character Pada Game Lost In Space". Tujuan penelitian ini yaitu menciptakan suatu game untuk sarana hiburan dan menambah edukasi tentang antariksa, menerapkan metode finite state machine untuk menentukan gerakan pada NPC (Non Player Character), dan menciptakan suatu game untuk meningkatkan pengalaman bertualang pemain. Adapun persamaan dari penelitian ini adalah menerapkan metode Finite State Machine untuk menentukan gerakan pada NPC (Non Player Character). Adapun perbedaan dari penelitian ini yaitu untuk memberikan edukasi mengenai virus COVID-19, lalu perbedaan pada tombol navigasi yang akan digunakan [2]. Pada tahun yang sama Bimantika pada penelitiannya yang berjudul "Pengembangan Game The Galaxy Menggunakan Metode FSM (Finite State Machine)" tujuan penelitian ini adalah merancang dan mengembangkan game dengan software Unity $3 D$ kemudian mengimplementasikan metode FSM dalam game peneliti. Adapun persamaan dari penelitian ini adalah pneggunaan metode yang digunakan yaitu finite state machine. Sedangkan perbedaan dalam penelitian ini adalah tipe game yang dibuat adalah 2D [3].

Selanjutnya Badruddin di tahun 2019 pada penelitiannya yang berjudul "Perancangan Dan Implementasi Finite State Machine Pada Game Castle Of Illustion". Tujuan penelitian ini adalah merancang sebuah game berbasis desktop dan mengimplementasikan metode Finite State Machine untuk NPC (Non Player Character) biasa dalam game. Adapun persamaan dari penelitian ini yaitu dimainkan untuk desktop dan menerapkan metode Finite State Machine. Perbedaan dari penelitian ini adalah genre dari game yang dibuat [4]. Pada tahun yang sama Nugroho pada penelitiannya yang berjudul "Desain Serious Game Sosialisasi Bencana Berbasis Model Teori Aktifitas" memiliki tujuan yaitu untuk membentuk kesadaran siswa atau kader-kader masyarakat di sekitar gunung berapi yang aktif dan kepedulian serta tanggung jawab dalam menanggulangi suatu bencana. Adapun persamaan dari penelitian ini yaitu metode yang digunakan serta tujuan dalam sosialisasi kepada masyarakat umum. Perbedaan dari penelitian ini adalah model game yang digunakan, yaitu menggabungkan game, pembelajaran, serta instruksional [5].

Setahun sebelumnya di tahun 2018 Andriansyah pada penelitiannya yang berjudul "Penggunaan Metode FSM Untuk Musuh Pada Game Mushroom Hunter". Tujuan penelitian ini adalah untuk menerapkan metode Finite State Machine. Adapun persamaan dari penelitian ini yaitu sama-sama menerapkan metode Finite State Machine. Yang menjadi perbedaan dengan game yang dibuat adalah alur permainan yang dibawakan dalam game [6]. 


\subsection{Pengertian Game}

Game merupakan sesuatu hal yang dapat dimainkan dengan aturan tertentu untuk membuat permainan lebih menarik sehingga terdapat hasil akhir berupa menang ataupun kalah. Game bertujuan untuk membuat pemain merasa senang, sarana hiburan dari rasa stress, serta untuk mengasah kemampuan otak.

Teori permainan awalnya ditemukan pada tahun 1944 yang dikemukakan oleh John von Neumann dan Oskar Morgenstern. Dalam teori tersebut berisi : "Permainan terdiri dari sekumpulan aturan yang dibuat untuk menciptakan situasi kompetitif atau suasana bersaing yang dilakukan oleh 2 orang atau lebih dengan tujuan untuk memenangkan pertandingan ataupun meminimalisir kemenangan lawan" [7].

\subsection{Artificial Intelligence}

Kecerdasan buatan (Artificial Intelligence) merupakan salah satu cabang dari ilmu computer yang mempelajari tentang bagaimana cara menguasai computer agar dapat membantu bahkan menggantikan pekerjaan yang biasa dikerjakan oleh manusia.

Menurut McCarthy (1956), AI merupakan konsep untuk mengetahui dan memodelkan proseproses berpikir manusia dan menciptakan mesin agar dapat mencerinkan perilaku manusia yang cerdas dan dapat mengambil keputusan secara otomatis. [8].

\subsection{Finite State Machine (FSM)}

Finite state machine merupakan sebuah uraian dalam metode untuk membuat control system yang menggambarkan tingkah laku dengan menggunakan tiga hal yang meliputi: State (keadaan), Event (Kejadian) dan Action (aksi). Pada suatu kondisi, system akan berada pada salah satu state, kemudian berpindah menuju state lain juka mendapatkan suatu masukan tertentu yang berasal dari dalam maupun perangkat luat komponen system tersebut.

Pergantian keadaan tersebut umumnya disertai aksi yang dilakukan oleh system ketika menanggapi suatu masukan. Jika dilihat menurut sifatnya, metode ini dapat digunakan sebagai dasar untuk merancang perangkat lunak pengendalian yang cepat tanggap dan aktual. [9].

\subsection{Pengertian Game Based Learning}

Menurut Coffey, Game-Based Learning merupakan suatu metode yang menggabungkan materi pembelajaran atau pendidikan ke dalam sebuah game yang bertujuan untuk membuat orang yang bermain tertarik untuk belajar melalui media pembelajaran seperti game. Game-Based Learning bermanfaat bagi anak-anak agar lebih mengikuti alur perkembangan jaman yang sudah maju ini dan berpartisipasi dalam masyarakat teknologi global [10].

\section{METODE PENELITIAN}

3.1 Perancangan Jalan Cerita dan Level pada Game

Jalan cerita pada game Escape from Cov-Madness ini berlatar dari seorang anak yang dihadapkan pada kondisi tidak menguntungkan, karena harus melewati kondisi dimana harus bertahan hidup dan menjaga kesehatan lantaran virus COVID-19 yang menyebar secara masif dan tiba-tiba. Anak tersebut diberi sosialisasi terkait virus COVID-19 dan cara penularannya pada orang lain. Di setiap awal permainan, anak tersebut berada pada posisi di luar rumah dan memiliki tujuan untuk pulang ke rumah dengan selamat dari ancaman COVID-19. Ia harus pintar membedakan mana orang yang terlihat sehat dan tidak sehat. Apabila ia bertemu dengan seseorang di jalan, ia harus menerapkan protocol COVID-19 dengan benar agar tidak tertular oleh ancaman COVID-19. Di tengah-tengah game terdapat beberapa item untuk mensterilkan bagian tubuh dari ancaman virus. Item tersebut berupa disinfektan, hand sanitizer, dan sabun cuci tangan. Di tiap level terdapat animasi edukasi terkait cara menghindari ancaman virus COVID-19. Dalam game Escape from Cov-Madness ini dibagi menjadi 3 level permainan, yaitu :

1. Level 1

Pada level ini, kondisi kota masih teratur. Tidak terdapat orang yang terjangkit oleh virus COVID-19. Orang - orang masih terlihat sehat semua. Walaupun begitu, masih ada objek yang dapat menurunkan imunitas tubuh pemain. Pemain harus menghindari setiap objek yang dapat menurunkan imunitas tubuh dan mengumpulkan objektif untuk menambah darah pemain dan menambah skor permainan.

2. Level 2

Pada level ini, kondisi kota terasa lumayan mencekam karena beberapa orang sudah terpapar virus COVID-19. Karakter utama sebisa mungkin harus menghindari orang yang terdampak virus COVID-19 ini, karena jika karakter utama menyentuh orang yang terdampak virus COVID-19 secara kontinu, maka game akan berakhir dan karakter utama akan diberikan status POSITIF COVID-19.

3. Level 3

Pada level terakhir ini, kondisi kota sangat mencekam dikarenakan banyaknya kasus COVID19 yang melonjak tajam. Banyak orang yang terjangkit virus COVID-19 tidak mengikuti protocol kesehatan dengan benar, banyak yang tidak memakai masker ketika sakit, memaksakan untuk keluar rumah ketika ia terinfeksi COVID-19. Karakter utama harus pintar mencari jalan keluar untuk menghindari kontak fisik dan menjaga jarak dari orang yang terjangkit virus COVID-19 tersebut.

\subsection{Perancangan Karakter Game}

Berikut adalah perancangan karakter apa saja yang terdapat pada game Escape from Cov-Madness yang dapat dilihat pada Tabe 1 berikut ini : 
Tabel 1 Perancangan karakter game

\begin{tabular}{|l|l|l|}
\hline No & Nama & Penjelasan \\
\hline 1. & $\begin{array}{l}\text { Karakter } \\
\text { Utama }\end{array}$ & $\begin{array}{l}\text { Karakter utama pada game ini, } \\
\text { user dapat menggerakkannya } \\
\text { dengan input keyboard. }\end{array}$ \\
\hline 2. & $\begin{array}{l}\text { NPC } \\
\text { (orang } \\
\text { sehat) }\end{array}$ & $\begin{array}{l}\text { NPC pada game ini tidak } \\
\text { bertindak sebagai musuh, } \\
\text { karena yang diperankan adalah } \\
\text { orang yang sehat/ tidak } \\
\text { terjangkit COVID-19. }\end{array}$ \\
\hline 3. & $\begin{array}{l}\text { Rintangan } \\
\text { (Virus } \\
\text { yang } \\
\text { menempel } \\
\text { pada } \\
\text { benda) }\end{array}$ & $\begin{array}{l}\text { Rintangan me memiliki aksi } \\
\text { yaitu menyerang karakter } \\
\text { utama ketika menyentuh } \\
\text { bagian dari rintangan ini. } \\
\text { Rintangan ini menempel pada } \\
\text { benda sekitar seperti tempat } \\
\text { pijakan karakter utama, dan } \\
\text { benda lain yang sering } \\
\text { disentuh oleh orang. }\end{array}$ \\
\hline 4. & Musuh 1 & $\begin{array}{l}\text { Musuh 1 ini memiliki aksi } \\
\text { yaitu bergerak patroli, jika } \\
\text { karakter utama menyentuh } \\
\text { musuh 1 ini, maka karakter } \\
\text { utama akan tertular sakit } \\
\text { ringan. }\end{array}$ \\
\hline 6. & $\begin{array}{l}\text { Musuh 2 ini memiliki aksi } \\
\text { yang mirip seperti musuh 1, } \\
\text { namun musuh ini memiliki } \\
\text { karakteristik diam (tidak ber } \\
\text { patroli). }\end{array}$ \\
\hline Musuh
\end{tabular}

3.3 Perancangan Background dan Rintangan Game Adapun rancangan background dan rintangan seperti pada Tabel 2.

Tabel 2 Perancangan background dan rintangan game

\begin{tabular}{|l|l|l|}
\hline No. & \multicolumn{1}{|c|}{ Nama } & \multicolumn{1}{|c|}{ Keterangan } \\
\hline 1. & $\begin{array}{l}\text { Background } \\
\text { Level 1 }\end{array}$ & $\begin{array}{l}\text { Background pada level 1 } \\
\text { menggambarkan kondisi } \\
\text { kota yang normal sebelum } \\
\text { gejolak COVID-19 }\end{array}$ \\
\hline 2. & $\begin{array}{l}\text { Background } \\
\text { Level 2 }\end{array}$ & $\begin{array}{l}\text { Background pada level 2 } \\
\text { menggambarkan kondisi } \\
\text { kota yang agak mencekam } \\
\text { karena adanya kasus } \\
\text { positif COVID-19 }\end{array}$ \\
\hline 3. & $\begin{array}{l}\text { Background } \\
\text { Level 3 }\end{array}$ & $\begin{array}{l}\text { Background pada level 3 } \\
\text { menggambarkan kondisi } \\
\text { kota yang sangat } \\
\text { berantakan dan mencekam } \\
\text { karena angka positif } \\
\text { COVID-19 ar yang } \\
\text { meningkat dan angka }\end{array}$ \\
\hline
\end{tabular}

\begin{tabular}{|l|l|l|}
\hline & & kematian yang tinggi. \\
\hline 4. & Lumpur & $\begin{array}{l}\text { Rintangan ini memiliki } \\
\text { bakteri dan virus yang } \\
\text { dapat mengurangi system } \\
\text { imun karakter utama. }\end{array}$ \\
\hline 5. & Ban Bekas & $\begin{array}{l}\text { Rintangan ini memiliki } \\
\text { bakteri dan virus yang } \\
\text { dapat mengurangi system } \\
\text { imun karakter utama }\end{array}$ \\
\hline 6. & $\begin{array}{l}\text { Tumpukan } \\
\text { Sampah }\end{array}$ & $\begin{array}{l}\text { Rintangan ini memiliki } \\
\text { bakteri dan virus dengan } \\
\text { intensitas yang tinggi } \\
\text { yang dapat mengurangi } \\
\text { system imun karakter } \\
\text { utama. }\end{array}$ \\
\hline 7. & $\begin{array}{l}\text { Bola } \\
\text { Lumpur }\end{array}$ & $\begin{array}{l}\text { Rintangan ini memiliki } \\
\text { bakteri dan virus yang } \\
\text { menempel pada benda } \\
\text { bola yang dapat } \\
\text { mengurangi system imun } \\
\text { karakter utama. }\end{array}$ \\
\hline 8. & Virus & $\begin{array}{l}\text { Rintangan ini bisa } \\
\text { menempel bada } \\
\text { permukaan benda maupun } \\
\text { bergerak bebas di udara. } \\
\text { Jika pemain bersentuhan } \\
\text { dengan rintangan ini, } \\
\text { maka darah pemain akan } \\
\text { berkurang. }\end{array}$ \\
\hline 9. & $\begin{array}{l}\text { Rintangan ini terletak } \\
\text { pada level 3 dikarenakan } \\
\text { kondisi lingkungan yang } \\
\text { sudah sangat kacau. }\end{array}$ \\
\hline
\end{tabular}

\subsection{Diagram FSM}

Adapun diagram FSM yang diterapkan untuk musuh dengan konsep yang berbeda pada tiap level yang ada. Berikut diagram FSM untuk tiap level, yaitu :

\section{Level 1}



Gambar 1 Tampilan diagram FSM pada level 1

Pada level 1, tipe musuh ini memiliki sifat yang pasif (tidak bergerak untuk menyerang pemain). Level 2 


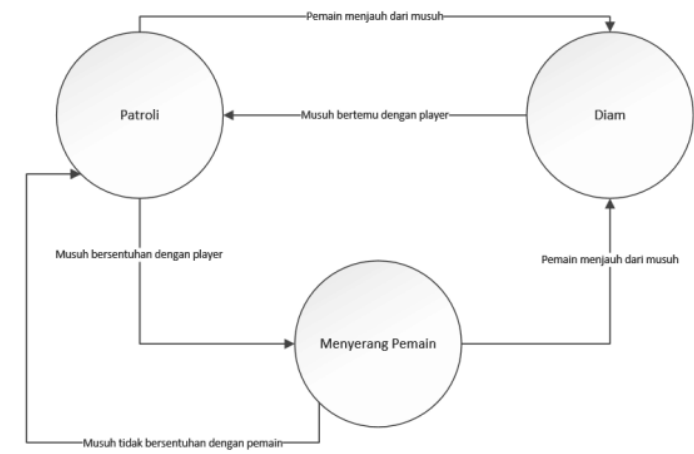

Gambar 2 Tampilan diagram FSM pada level 2

Pada level 2, tipe musuh ini memiliki sifat menyerang pemain dengan cara bergerak patroli ke kanan dan ke kiri. Metode FSM ini akan diterapkan pada musuh dengan tipe musuh berpatroli.

3. Level 3

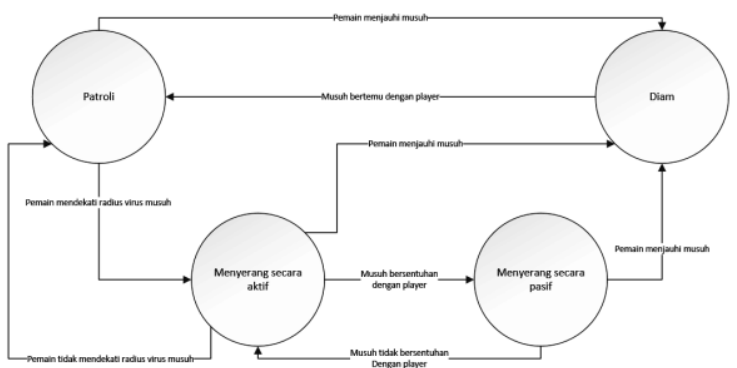

Gambar 3 Tampilan diagram FSM pada level 3

Pada level 3, tipe musuh memiliki kemampuan untuk menyerang musuh dari jauh ataupun dari dekat.

\section{HASIL DAN PEMBAHASAN}

\subsection{Tampilan Menu Utama Game}

Pada tampilan menu utama dalam game "Escape from Cov-Madness" terdapat 3 tombol, yaitu tombol untuk memulai game, tombol "about" yang berisikan penjelasan tentang game dan pembuat game itu sendiri, lalu ada tombol untuk keluar dari game. Seperti yang ditunjukkan pada Gambar 4.

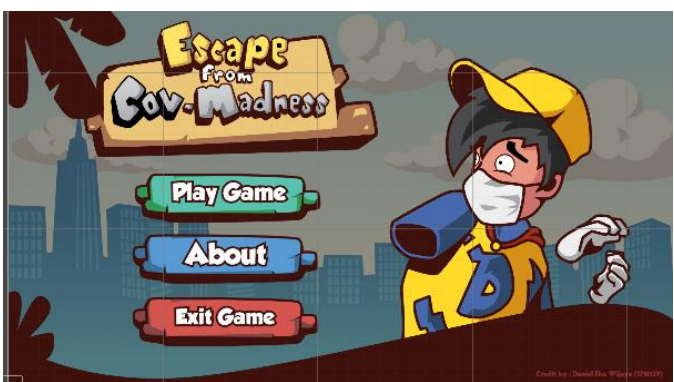

Gambar 4 Tampilan Menu Utama Game

\subsection{Tampilan Menu Pause Game}

Pada tampilan menu pause, terdapat 3 tombol untuk navigasi. Tombol tersebut yaitu tombol untuk melanjutkan permainan, tombol untuk mengulang kembali level dalam game, serta tombol untuk kembali ke menu utama. Seperti yang ditunjukkan pada Gambar 5.

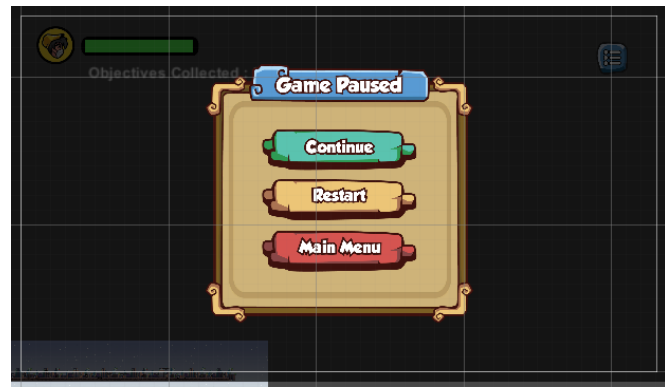

Gambar 5 Tampilan Menu Pause Game

\subsection{Tampilan Info Menu pada Game}

Pada tampilan info menu, terdapat informasi mengenai objektif game yang berkaitan dengan protocol kesehatan selama pandemic virus COVID-19. Seperti yang ditunjukkan pada Gambar 6.

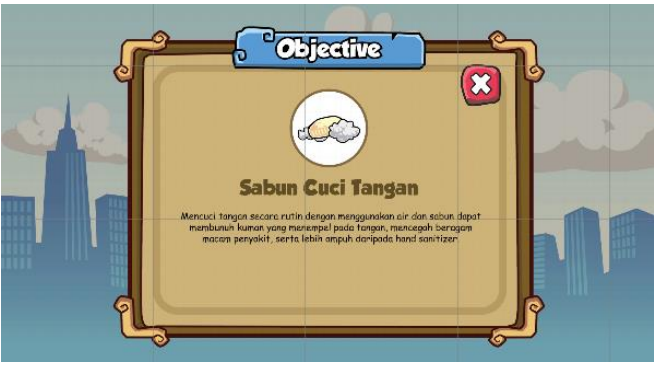

Gambar 6 Tampilan Info Menu pada Game

\subsection{Tampilan Game Level 1}

Pada tampilan game level 1 ini, berlatar perkotaan pada pagi hari. Suasana dalam game masih tenang karena tidak ada virus COVID-19 yang melanda. Pada level ini terdapat NPC serta rintangan yang akan menghalangi player untuk memenangkan permainan. Seperti yang ditunjukkan pada Gambar 7.

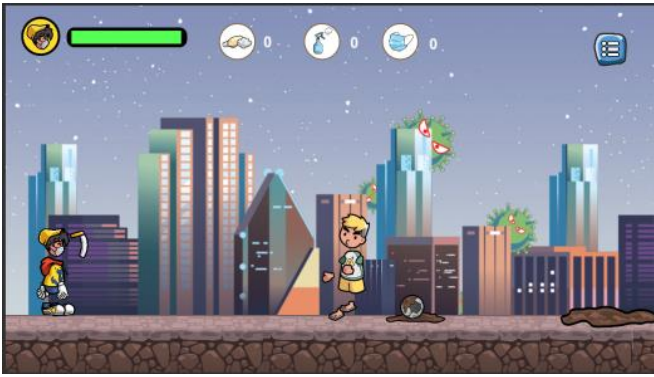

Gambar 7 Tampilan Game Level 1

\subsection{Tampilan Mini Games}

Pada tampilan mini-games ini, berisikan pertanyaan terkait virus COVID-19 beserta penjelasan terkait virus COVID-19 ketika pemain selesai memilih jawaban yang ada dalam mini-games tersebut. seperti yang ditunjukkan pada Gambar 8. 


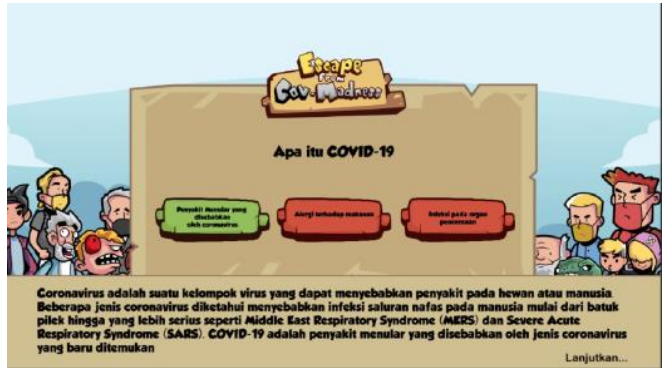

Gambar 8 Tampilan Mini Games

\subsection{Tampilan Game Level 2}

Pada tampilan game level 2 ini, berlatar perkotaan pada sore hari. Suasana dalam game sudah agak kacau dikarenakan virus COVID-19 yang sudah menyebar, namun masih belum masif. Seperti yang ditunjukkan pada Gambar 9.

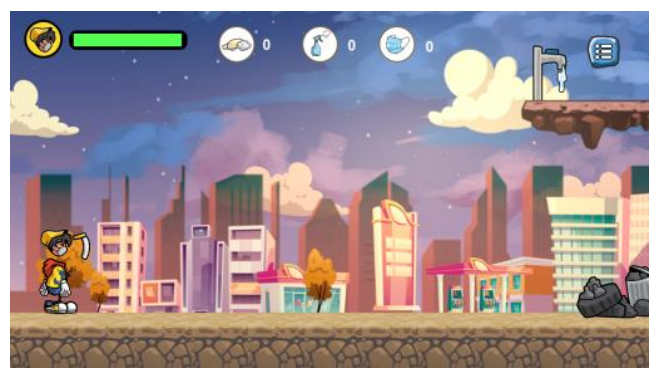

Gambar 9 Tampilan Game Level 2

\subsection{Tampilan Game Level 3}

Pada tampilan game level 3 ini, berlatar perkotaan pada malam hari. Suasana dalam game sudah sangat kacau dikarenakan virus COVID-19 yang sudah menyebar secara massif, hampir semua orang terinfeksi COVID-19. Seperti yang ditunjukkan pada Gambar 10.



Gambar 10 Tampilan Game Level 3

\subsection{Pengujian Fungsional}

Pengujian ini berfungsi untuk menguji apakah dalam game "Escape from Cov-Madness" seluruh fungsinya berjalan dengan baik atau masih ada beberapa error yang terjadi. Hasil pengujian fungsionalitas dapat dilihat pada Tabel 3 .
Tabel 3 Pengujian Fungsional

\begin{tabular}{|c|c|c|}
\hline No & Item Uji & Hasil \\
\hline 1. & Tampilan Menu Utama & Sesuai \\
\hline 2. & Tampilan Menu About & Sesuai \\
\hline 3. & Tampilan Level 1 & Sesuai \\
\hline 4. & Tampilan Level 2 & Sesuai \\
\hline 5. & Tampilan Level 3 & Sesuai \\
\hline 6. & Backsound Game & Sesuai \\
\hline 7. & Tampilan layar ketika menang & Sesuai \\
\hline 8. & Tampilan layar ketika kalah & Sesuai \\
\hline 9. & Tombol Navigasi & Sesuai \\
\hline 10. & Health Point Karakter Utama & Sesuai \\
\hline 11. & Mengumpulkan Collectable Objectives & Sesuai \\
\hline 12. & Pemain menerima Damage & Sesuai \\
\hline 13. & Pemain menerima HealthPoint & Sesuai \\
\hline 14. & Skor Akhir Objektif & Sesuai \\
\hline 15. & Berpindah Scene ketika Menang & Sesuai \\
\hline 16. & Tampilan Info Menu ketika menyentuh Objektif & Sesuai \\
\hline 17. & Animasi Karakter saat diam/ bergerak & Sesuai \\
\hline 18. & Animasi musuh & Sesuai \\
\hline 19. & Animasi ketika HP berkurang & Sesuai \\
\hline 20. & Animasi ketika HP bertambah & Sesuai \\
\hline 21. & Tombol Pause Level & Sesuai \\
\hline 22. & Tombol Resume Level & Sesuai \\
\hline 23. & Tombol Restart Level & Sesuai \\
\hline 24. & Tombol Back To Home & Sesuai \\
\hline 25. & Tombol Continue Level & Sesuai \\
\hline 26. & Musuh Patroli & Sesuai \\
\hline 27. & Musuh menyerang pemain & Sesuai \\
\hline & & \\
\hline
\end{tabular}

\subsection{Pengujian Desktop}

Pada pengujian ini, game dijalankan pada berbagai perangkat desktop untuk menguji performa game "Escape from Cov-Madness". Hasil pengujian perangkat dapat dilihat pada Tabel 4.

\begin{tabular}{|c|c|c|c|c|c|c|c|c|}
\hline No & $\begin{array}{c}\text { Merk } \\
\text { Laptop /PC }\end{array}$ & $\begin{array}{c}\text { Versi } \\
\text { Wind } \\
\text { ows }\end{array}$ & Prosesor & $\begin{array}{l}\text { Kartu } \\
\text { Grafis }\end{array}$ & RAM & $\begin{array}{c}\text { Resolusi } \\
\text { Layar }\end{array}$ & $\begin{array}{c}\text { Konsumsi } \\
\text { RAM } \\
\text { ketika } \\
\text { game } \\
\text { dijalankan }\end{array}$ & Hasil Uji \\
\hline 1. & PC rakitan & 10 & $\begin{array}{c}\text { AMD FX- } \\
8350\end{array}$ & $\begin{array}{l}\text { NVDIA } \\
\text { GTX } 950\end{array}$ & $8 \mathrm{~GB}$ & $\begin{array}{c}1920 \mathrm{x} \\
1080\end{array}$ & $127 \mathrm{MB}$ & $\begin{array}{c}\text { Berjalan } \\
\text { lancar }\end{array}$ \\
\hline 2. & $\begin{array}{l}\text { Toshiba } \\
\text { C40D }\end{array}$ & 8 & AMD A4 & - & $3 \mathrm{~GB}$ & $\begin{array}{c}1366 \mathrm{x} \\
768\end{array}$ & $144,8 \mathrm{MB}$ & $\begin{array}{c}\text { Berjalan } \\
\text { lancar }\end{array}$ \\
\hline 3. & MSI GF63 & 10 & $\begin{array}{c}\text { Intel Core } \\
\text { i5 }\end{array}$ & - & $8 \mathrm{~GB}$ & $\begin{array}{c}1920 \mathrm{x} \\
1080\end{array}$ & $149,9 \mathrm{MB}$ & $\begin{array}{c}\text { Berjalan } \\
\text { Lancar }\end{array}$ \\
\hline 4. & Inforce & 7 & $\begin{array}{c}\text { Intel } \\
\text { Celeron }\end{array}$ & - & $2 \mathrm{~GB}$ & $\begin{array}{c}1366 \mathrm{x} \\
728\end{array}$ & $154,4 \mathrm{MB}$ & $\begin{array}{c}\text { Berjalan } \\
\text { lancar }\end{array}$ \\
\hline 5. & Lenovo & 10 & $\begin{array}{c}\text { Intel Core } \\
\text { i5 }\end{array}$ & - & $8 \mathrm{~GB}$ & $\begin{array}{c}1366 \mathrm{x} \\
768\end{array}$ & $133,6 \mathrm{MB}$ & $\begin{array}{c}\text { Berjalan } \\
\text { lancar }\end{array}$ \\
\hline 6. & Dell G3 & 10 & \begin{tabular}{|c} 
Intel Core \\
i5
\end{tabular} & \begin{tabular}{|c|} 
NVIDIA \\
GTX \\
1050
\end{tabular} & $8 \mathrm{~GB}$ & $\begin{array}{c}1920 \mathrm{x} \\
1080\end{array}$ & $132 \mathrm{MB}$ & $\begin{array}{c}\text { Berjalan } \\
\text { lancar }\end{array}$ \\
\hline 7. & Acer Predator & 10 & $\begin{array}{c}\text { Intel Core } \\
\text { i } 7\end{array}$ & \begin{tabular}{|c} 
NVDIA \\
GTX \\
1050Ti
\end{tabular} & $8 \mathrm{~GB}$ & $\begin{array}{c}1920 \mathrm{x} \\
1080\end{array}$ & $132,6 \mathrm{MB}$ & $\begin{array}{c}\text { Berjalan } \\
\text { lancar }\end{array}$ \\
\hline 8. & $\begin{array}{l}\text { Lenovo } \\
\text { Ideapad } \\
\text { IP330 }\end{array}$ & 10 & $\begin{array}{c}\text { Intel Core } \\
\text { i5 }\end{array}$ & - & $8 \mathrm{~GB}$ & $\begin{array}{c}1366 \mathrm{x} \\
768\end{array}$ & $130,7 \mathrm{MB}$ & $\begin{array}{c}\text { Berjalan } \\
\text { lancar }\end{array}$ \\
\hline 9. & $\begin{array}{l}\text { HP } 1000 \\
\text { Notebook }\end{array}$ & 7 & AMD E1 & - & $2 \mathrm{~GB}$ & $\begin{array}{c}1366 \mathrm{x} \\
728\end{array}$ & $143,5 \mathrm{MB}$ & $\begin{array}{c}\text { Berjalan } \\
\text { lancar }\end{array}$ \\
\hline 10. & \begin{tabular}{|c|} 
HP Laptop \\
15-EFOXXX
\end{tabular} & 10 & $\begin{array}{c}\text { AMD } \\
\text { Ryzen } 7\end{array}$ & - & 8GB & $\begin{array}{c}1366 \mathrm{x} \\
728\end{array}$ & $152 \mathrm{MB}$ & $\begin{array}{l}\text { Berjalan } \\
\text { lancar }\end{array}$ \\
\hline 11. & $\begin{array}{c}\text { Asus } \\
\mathrm{X} 555 \mathrm{QG}\end{array}$ & 10 & AMD A10 & - & $8 \mathrm{~GB}$ & $\begin{array}{c}1366 \mathrm{x} \\
728\end{array}$ & $145,2 \mathrm{MB}$ & $\begin{array}{c}\text { Berjalan } \\
\text { Lancar }\end{array}$ \\
\hline
\end{tabular}




\subsection{Pengujian User}

Pada pengujian user ini, game "Escape from Cov-Madness" dimainkan oleh 12 orang pengguna menggunakan perangkat laptop/ komputer yang berbeda-beda. Target pengujian ini ditujukan kepada masyarakat dengan umur yang berbeda-beda. Hasil pengujian user dapat dilihat pada Tabel 5 .

Tabel 5 Pengujian User

\begin{tabular}{|c|l|c|c|}
\hline \multirow{2}{*}{ No. } & \multicolumn{1}{|c|}{ Pertanyaan } & \multicolumn{2}{c|}{ Penilaian } \\
\cline { 2 - 4 } & \multicolumn{1}{|c|}{$\begin{array}{l}\text { Ya } \\
\text { Apakah game ini } \\
\text { menarik untuk } \\
\text { dimainkan? }\end{array}$} & $100 \%$ & $0 \%$ \\
\hline 2. & $\begin{array}{l}\text { Apakah animasi pada } \\
\text { game ini menarik? }\end{array}$ & $100 \%$ & $0 \%$ \\
\hline 3. & $\begin{array}{l}\text { Apakah kontrol pada } \\
\text { game ini berjalan } \\
\text { lancar? }\end{array}$ & $91.7 \%$ & $8.3 \%$ \\
\hline 4. & $\begin{array}{l}\text { Apakah game ini } \\
\text { memberikan pesan } \\
\text { moral kepada } \\
\text { pemainnya? }\end{array}$ & $100 \%$ & $0 \%$ \\
\hline 5. & $\begin{array}{l}\text { Apakah mini-games } \\
\text { pada game ini dapat } \\
\text { memberikan wawasan } \\
\text { seputar COVID-19? }\end{array}$ & $100 \%$ & $0 \%$ \\
\hline 6. & $\begin{array}{l}\text { Apakah karakter musuh } \\
\text { dapat menyerang } \\
\text { pemain dan membuat } \\
\text { darah pemain } \\
\text { berkurang? }\end{array}$ & $100 \%$ & $0 \%$ \\
\hline 7. & $\begin{array}{l}\text { Apakah level tiap game } \\
\text { dapat berjalan tanpa ada } \\
\text { kendala? }\end{array}$ & $100 \%$ & $0 \%$ \\
\hline 8. & $\begin{array}{l}\text { Apakah metode Finite } \\
\text { State Machine dapat } \\
\text { berjalan pada game ini? }\end{array}$ & $100 \%$ & $0 \%$ \\
\hline 9. & $\begin{array}{l}\text { Apakah metode Game- } \\
\text { Based Learning dapat } \\
\text { terlihat pada game ini? }\end{array}$ & $100 \%$ \\
\hline
\end{tabular}

\section{KESIMPULAN DAN SARAN}

\subsection{Kesimpulan}

Adapun kesimpulan yang dapat penulis sampaikan setelah melakukan pengembangan dan pengujian game "Escape from Cov-Madness" yang menggabungkan metode Finite State Machine dengan metode Game Based Learning antara lain yaitu:

1. Pada pengujian fungsionalitas menunjukkan hasil sempurna, yang berarti game ini dapat berjalan secara lancar sesuai fungsinya.

2. Dari hasil pengujian perangkat desktop, dapat disimpulkan bahwa game ini dapat dijalankan pada Sistem Operasi Windows dengan berbagai spesifikasi minimum ataupun maksimum.

3. Dari hasil pengujian perangkat desktop, semakin kecil resolusi layar atau dengan adanya kartu grafis dalam laptop/ pc maka konsumsi memory pada game akan semakin berkurang.

4. Dari hasil pengujian kepada responden, semua kontrol dalam game dapat berjalan cukup baik.

5. Dari hasil pengujian, game "Escape from CovMadness" ini dapat memberikan wawasan terkait sosialisasi pencegahan COVID-19.

6. Dari hasil pengujian, metode FSM dapat diterapkan dengan benar dalam game "Escape from CovMadness".

7. Dari hasil pengujian terhadap responden, didapat hasil yang memuaskan pada bagian metode yang digunakan dalam game. Hal ini menunjukkan bahwa kombinasi metode Finite State Machine dan metode Game-Based Learning dapat diterapkan dengan baik pada game "Escape from Cov-Madness".

\subsection{Saran}

Untuk pengembangan game yang lebih baik, ada beberapa saran pada game "Escape from Cov-Madness" yaitu :

1. Diharapkan game ini dapat dikembangkan lebih luas pada Platform Game Online Steam agar bisa mendapatkan banyak masukan dari pemain yang mengunduh game ini.

2. Menambahkan animasi untuk bagian informasi objektif dalam game agar tampilan terlihat lebih menarik.

3. Menambahkan efek transisi seperti loading game untuk menambah pengalaman dalam bermain yang lebih seru.

4. Menambahkan efek transisi seperti loading game untuk menambah pengalaman dalam bermain yang lebih seru.

\section{DAFTAR PUSTAKA}

[1] Pane, M. D. C 2020, Virus Corona, Alodokter, 7 Desember 2020 , https://www.alodokter.com/virus-corona

[2] Alqorni, M. H., 2017. Penerapan Metode Finite State Machine untuk Non Player Character pada Game Lost in Space. JATI (Jurnal Mahasiswa Teknik Informatika), 1(2), 111-119.

[3] Bimantika, $\mathrm{R}$ 2017. PENGEMBANGAN GAME THE GALAXY MENGGUNAKAN METODE FSM (FINITE STATE MACHINE). JATI (Jurnal Mahasiswa Teknik Informatika), 1(1), 180-187.

[4] Badruddin, A 2019. PERANCANGAN DAN IMPLEMENTASI FINITE STATE MACHINE PADA GAME "CASTLE OF ILLUSION" (Doctoral dissertation, Institut Teknologi Nasional Malang).

[5] Nugroho, F., Yuniarno, E. M., \& Hariadi, M 2019. Desain Serious Game Sosialisasi Bencana Berbasis Model Teori Aktifitas. Jurnal Mnemonic, 2(1), 59-66.

[6] Andriansyah, R. T 2018. PENGGUNAAN METODE FSM UNTUK MUSUH PADA GAME MUSHROOM HUNTER. JATI (Jurnal 
Mahasiswa Teknik Informatika), 2(1), 582588Irawan, J.D., Prasetio S., Wibowo, S.A. 2018, Early Warning System For Building Automation System, Jurnal Teknologi Informasi Vol. 6 No. 2.

[7] Von Neumann, J., \& Morgenstern, O 2007. Theory of games and economic behavior (commemorative edition). Princeton university press.
[8] Dahria, M 2008. Kecerdasan Buatan Jurnal SAINTIKOM, p. 185.

[9] Setiawan, I 2006. Perancangan Software Embedded System Berbasis FSM. Semarang: Universitas Diponegoro.

[10] Coffey, H., 2008. Digital Games Based Learning.http://www.learnnc.org/lp/pages/4970 \#noteref1. 3 Januari 2021 